\title{
God, Tragedy, and the Near-Death Experience: Evaluating Kushner's Perspectives on Theodicy
}

\author{
John C. Gibbs, Ph.D. \\ The Ohio State University
}

\begin{abstract}
This article evaluates Harold Kushner's original and reconstructed perspectives on God and the theodicic problem on the basis of research on the near-death experience (NDE) and related phenomena. In response to a personal tragedy, Kushner reconstructed his thinking about God and tragedy from his original Causation-Power perspective to an Inspiration-Love perspective. The Causation-Power perspective posits that God causes human events and that tragic events do not actually contradict God's purpose or will, although tragic events may result from the human freedom to disobey God and suffer punitive consequences. In the Inspiration-Love perspective, human freedom expands to mean that God does not cause all events: God does not cause tragedy, suffers with the sufferer, and can intervene against tragic events only by inspiring people to cope with tragedy and care for others. Although the research findings are consistent with Kushner's emphasis on love and inspiration, the theme of divine power and purpose is also evident. Hence, Kushner should not have rejected entirely his early (Causation-Power) perspective. Identified in the research are forms of "inspiration" that Kushner did not take into account in his reconstructed (Inspiration-Love) view. The Causation-Power and Inspiration-Love perspectives seem incompatible and neither alone solves the theodicic problem. Nonetheless, they do complement one another; a resolution would permit an integrative understanding of God and tragedy.
\end{abstract}

In 1966, a young rabbi named Harold Kushner learned that his threeyear-old son had the terminal disease progeria, or accelerated aging.

John C. Gibbs, Ph.D., is Professor of Psychology at The Ohio State University. The author thanks Harold Brooks, Russ Crabtree, Jon Gibbs, Lowell Gibbs, Stephanie Gibbs, Valerie Gibbs, Sophia Gibbs Kim, Peter Kreeft, Harold Kushner, Herb Mirels, Clark Power, Kenneth Ring, Michael Sabom, John Snarey, Mike Vasey, Peter Viereck, and Charles Wenar for their helpful comments on preliminary versions of this article. The author also thanks Sr. Alena Bernert, Maggie Callanan, Brenda Dunne, Ankur Garg, Judy Guggenheim, Norman Knapp, Ron Mallett, Elena Mustakova-Possardt, Lea Queener, Lew Queener, and Steve Rice for their encouragement. Reprint requests should be addressed to Dr. John C. Gibbs at the Department of Psychology, The Ohio State University, 142 Townshend Hall, 1885 Neil Avenue, Columbus, Ohio 43210. 
This tragic news provoked in Kushner pain, suffering, and a profound crisis of faith. Rather than abandon his faith in God, Kushner undertook through the subsequent decade a fundamental reconstruction of his perspective on God and the problem of theodicy-how to reconcile the good and loving attributes of God with human tragedy and suffering. (By "tragedy," I mean not the classical definition of the inexorable consequence of a fatal flaw in a heroic victim, but the popular definition of an apparently unnecessary, senseless, or unfair event, such as an accident, victimization, physical handicap, illness, or natural disaster, that results in grievous human suffering or death.) Kushner shared his reconstructed perspective on tragedy not only with his congregation but with the world in his 1981 best-seller When Bad Things Happen to Good People.

My aim in this article is to compare and evaluate Kushner's original and reconstructed perspectives on the basis of the findings and implications of studies on the near-death experience (NDE) and related phenomena. The first section of the article will describe the development of Kushner's theological thought, from his original to his reconstructed perspective on God and tragedy, with a depiction of both perspectives as positions on the problem of theodicy. The second section will suggest the relevance of the NDE and related phenomena to theological issues such as theodicy. The third section will apply near-death and related research to an evaluation of Kushner's original and reconstructed perspectives, identifying compatibilities between the research and both perspectives. I conclude that the perspectives are complementary and heuristic towards an integrative understanding of God and tragedy.

\section{Faith, Crisis, and Reconstruction}

In When Bad Things Happen to Good People, Kushner described how the tragic news of his son's illness provoked him to "rethink" (p. 1) or reconstruct his faith. For a fine-grained grasp of his rethinking, I will quote passages from his book extensively. The key thesis emerging from his crisis of faith was that God does not directly cause, will, or arrange all human events. In the course of his crisis and rethinking, Kushner transformed his faith from what we will call the "Causation-Power" Perspective to what we will call the "Inspiration-Love" Perspective on God. 


\section{Kushner's Original Faith: The Causation-Power Perspective}

Kushner's original perspective on God could be called "CausationPower" or "divine determinism," insofar as God is seen as the all-powerful Creator who purposefully - and supernaturally, if need be-causes and controls events. God is so strongly in charge of human events that apparent randomness, chaos, or chance ("accident") does not exist. Although God is in charge, He has given humans the freedom to choose either to love and obey Him or to reject and rebel-but with sanctions for disobedience; hence, some human suffering is punishment for the human sin of disobedience. Attributions of suffering to disobedience or moral transgression are evident in many cultures (Shweder, Much, Mahapatra, and Park, 1997). Whatever its explanation, human suffering is seen as consistent with God's just will and purpose. Ostensibly bad things happen, in other words, to those who somehow need or deserve them.

Kushner described Causation-Power as the faith of his childhood, a traditional view which he found to be "comforting" (p. 44) and reassuring:

Like most people, my wife and I had grown up with an image of God as an all-wise, all-powerful parent figure who would treat us as our earthly parents did, or even better. If we were obedient and deserving, He would reward us. If we got out of line, He would discipline us, reluctantly but firmly. He would protect us from being hurt or from hurting ourselves, and would see to it that we got what we deserved in life. (p. 3)

Of course, Kushner knew of occasional cases of misfortune seemingly irrelevant or out of proportion to the need for punishment or firm discipline. These cases were anomalies: apparently bad things happening to apparently good people for no apparent good reason.

Like most people, I was aware of the human tragedies that darkened the landscape-the young people who died in car crashes, the cheerful, loving people wasted by crippling diseases, the neighbors and relatives whose retarded or mentally ill children people spoke of in hushed tones. But that awareness never drove me to wonder about God's justice, or to question His fairness. I assumed that He knew more about the world than I did. (p. 3)

\section{Kushner's Crisis of Faith}

Because Kushner could defer to God's omniscience or infinite wisdom, human tragedies did not provoke any crisis of faith - until one of them 
hit home. Through his son's fatal disease and suffering, Kushner himself came to be "hurt by life" (p. 5). Kushner's crisis began "that day in the hospital when the doctor told us about Aaron and explained what progeria meant" (p. 3):

How does one handle news like that? ... It didn't make sense. I had been a good person. I had tried to do what was right in the sight of God. More than that, I was living a more religiously committed life than most people I knew, people who had large, healthy families. I believed that I was following God's ways and doing His work. How could this be happening to my family? If God existed, if He was minimally fair, let alone loving and forgiving, how could He do this to me?

And even if I could persuade myself that I deserved this punishment for some sin of neglect or pride that I was not aware of, on what grounds did Aaron have to suffer? He was an innocent child, a happy, outgoing three-year-old. Why should he have to suffer physical and psychological pain every day of his life? (p. 2)

After hearing the tragic news concerning his own son, Kushner could no longer simply defer to God's infinitely superior knowledge. Now, an undeniably bad thing was happening to an undeniably good person; when the fatal illness struck his innocent child, practically at the onset of life, the event seemed especially senseless and unfair. Other apparently pointless, unnecessary, or unfair misfortunes now had to be faced and pondered: what about senseless murders and fatal practical jokes? Not only moral but natural evils, in addition to premature fatal illness, came under question: what about casualties and suffering from natural disasters, such as floods, earthquakes, and hurricanes?

In the course of his anguish and reflection, Kushner came to see two "serious limitations" (p. 10) to the Causation-Power perspective: first, its poor fit with actual experience; and second, its generating of debilitating and isolating emotions such as misdirected anger. First, and more fundamentally, it simply did not "fit the facts" (p. 10); hence, the comfort and reassurance it offered was false. Especially once one has had a personal tragedy, the facts or anomalies "press upon [one] from every side.... [in today's] era of mass communication" (pp. 11 and 10). One such colossal "fact" was the Holocaust:

Even if I could accept the death of an innocent individual now and then without having to rethink all of my beliefs, the Holocaust represents too many deaths, too much evidence against the view that "God is in charge and He has His reasons." (p. 82)

If God is in charge and causes things to happen, what could be His "reasons" for causing so much tragedy and suffering? Kushner argued 
that like the Causation-Power perspective itself, that is, the thesis that God is simply in charge and causes or purposes events, the "reasons" proposed in its defense fit poorly with the facts of experience. I have already noted one Causation-Power reason for human suffering: perhaps the person had been out of line or disobedient and needed to be disciplined or punished. Kushner related this reason to "blame the victim" beliefs: "If the Jews had behaved differently, Hitler would not have been driven to murder them. If the young woman had not been so provocatively dressed, the man would not have assaulted her" (p. 39).

Such Causation-Power interpretations of tragedy as God's punishment fell flat with Kushner, who knew perfectly well that his young son had committed no sin of irresponsibility or negligence, certainly none to warrant fatal suffering. Nor did Kushner accept the Causation-Power Original Sin doctrine, that his son deserved punishment because of Adam's original disobedience. Imputing blame to an innocent victim is motivated, according to Melvin Lerner (1980), by a human need to see the world as just, or the relations between actions as balanced, even at the cost of distorting the facts: something bad should happen to a bad, not a good, person. Insofar as it encourages the gratuitous attribution of "bad-deservingness" to an innocent person, the "just-world hypothesis" is viewed as a source of bias in the interpretation of human events.

The just-world hypothesis or blame-the-victim tendencies are sometimes applied to make sense out of the effects of natural evils. Kushner wrote, however, that one is hard-pressed to find evidence that natural calamities such as earthquakes or hurricanes reflect God's purposeful and just will: "I would not venture to predict the path of a hurricane on the basis of which communities deserve to be lashed and which ones to be spared" (p. 53).

One hurricane might veer off to sea, sparing the coastal cities, but it would be a mistake to see any evidence of pattern or purpose to that. Over the course of time, some hurricanes will blow harmlessly out to sea, while others will head into populated areas and cause devastation. The longer you keep track of such things, the less of a pattern you will find. (p. 54, emphasis added)

Kushner also saw no evidence for a pattern in the consequences of human evil:

I visit a woman in the hospital whose car was run into by a drunken driver running a red light. Her vehicle was totally demolished, but miraculously she escaped with only two cracked ribs and a few superficial cuts from flying glass. She looks up at me from her hospital bed and says, "Now I know there is a God. If I could come out of that alive 
and in one piece, it must be because He is looking out for me up there." I smile and keep quiet ... . But my mind goes back to a funeral I conducted two weeks earlier, for a young husband and father who died in a similar drunk-driver collision; and I remember another case, a child killed by a hit-and-run driver while roller-skating; and all the newspaper accounts of lives cut short in automobile accidents. The woman before me may believe that she is alive because God wanted her to survive, and I am not inclined to talk her out of it, but what would she or I say to those other families? That they were less worthy than she, less valuable in God's sight? That God wanted them to die at that particular time and manner, and did not choose to spare them? (pp. 48-49)

If suffering from natural or human evil is not intended as a punishment, or if escape from evil does not reflect divine favor, could God have some other reason for causing suffering? Other reasons may "bend" not the nature of the afflicted person, as "not so good after all," that is, deserving of punishment, but rather the nature of the event, as in one sense or another "not so bad after all." Perhaps the tragedy was not so bad because it might have been (1) an appropriate time for that person's life to end; (2) a privileged burden or opportunity for that person to pass a test and grow spiritually; or (3) only a temporary injustice to be rectified in due time.

Kushner used journalistic investigations to help him evaluate whether the "appropriate time" explanation of accidents or disasters fits the facts. Is there some factual basis for inferring that the deaths in a fatal airplane accident, for example, were not so unfair or senseless or arbitrary after all, that the people's deaths were not so tragic, that it was for them the "right time" to die? Journalists have on occasion investigated such tragedies with such questions in mind (for example, Chua-Eoan, 1996). Consider, Kushner wrote,

two hundred and fifty passengers on an airplane that crashes. It strains the imagination to claim that every single one of them had just passed a point of resolution in his life. The human-interest stories in the newspapers after a plane crash seem to indicate the opposite-that many of the victims were in the middle of important work, that many left young families and unfulfilled plans. (p. 17; emphasis added)

Could the apparently "bad" event actually be a privileged burden or spiritual opportunity? Kushner also considered the Causation-Power rationale that "God sends ... tests and afflictions only to people $\mathrm{He}$ knows are capable of handling them, so that they and others can learn the extent of their spiritual strength" (p. 25). Kushner wrote that he himself as the parent of a handicapped child did not feel "privileged" and found no comfort in such a notion. Nor did the argument, that God 
only sends what can be endured and learned from, fit the facts of his pastoral experience:

My experience, alas, has been otherwise. I have seen people crack under the strain of unbearable tragedy. I have seen marriages break up after the death of a child, because the parents blamed each other for not taking proper care or for carrying the defective gene, or simply because the memories they shared were unendurably painful. I have seen some people made noble and sensitive through suffering, but I have seen many more people grow cynical and bitter. I have seen people become jealous of those around them, unable to take part in the routines of normal living. I have seen cancers and automobile accidents take the life of one member of a family, and functionally end the lives of five others, who could never again be the normal, cheerful people they were before the disaster struck. If God is testing us, He must know by now that many of us will fail the test. If He is only giving us burdens we can bear, I have seen Him miscalculate far too often. (p. 26)

Also based on his pastoral experience, Kushner attacked the Causation-Power rationale that unjust events are only temporarily so, that in due time-God's time-people do get what they deserve:

I think of an acquaintance of mine who built up a modestly successful business through many years of hard work, only to be driven into bankruptcy when he was cheated by a man he had trusted. I can tell him that the victory of evil over good is only temporary, and that other person's evil ways will catch up to him. But in the meantime, my acquaintance is a tired, frustrated man, no longer young, and grown cynical about the world. Who will send his children to college, who will pay the medical bills that go with advancing age, during the years it takes for God's justice to catch up with him? (p. 14)

Do people "get what they deserve" after they die, in heaven or hell? Although Kushner could not experientially evaluate such notions, he expressed concern that such notions can breed complacency, serving as "an excuse for not being troubled or outraged by injustice around us, and not using our God-given intelligence to try to do something about it" (p. 29).

Perhaps even worse than complacency is the anger that can be engendered by the Causation-Power perspective. Complacency and especially misdirected anger represent the second "serious limitation" Kushner saw with the Causation-Power perspective, namely, that it can lead to debilitating emotion. Although the view that tragedy is deserved may not be supported by the facts, if it is believed, the detrimental emotional impact is nonetheless powerful. Kushner in his pastoral work encountered many Causation-Power believers angry at God for having caused their tragedy, and also feeling guilty or fearful because of their 
anger. Some suppressed their anger at God, not daring to express it for fear He would punish them again. As C. S. Lewis (1961) reflected in the midst of his own personal tragedy, the death of his wife, whom he had only recently married with great joy late in his life: "Our elders submitted and said, 'Thy will be done.' How often had bitter resentment been stifled through sheer terror and an act of love-yes, in every sense, an act-put on to hide the operation?" (p. 6).

Others with a traditional faith who experience tragedy direct their anger exclusively at themselves, trying to convince themselves that they did after all deserve the tragic event, and experiencing debilitating guilt and depression to the extent that they succeed. All feel alienated from God, alone, isolated from potential sources of help-all experiencing such emotional damage from what Kushner argued are erroneous beliefs.

\section{The Causation-Power Perspective and Theodicy}

Either God cannot abolish evil or he will not; if he cannot, he is not all-powerful; if he will not, he is not all-good.

St. Augustine (cited in Lorimer, 1990, p. 233)

The God of Kushner's childhood faith was a God of love and goodness, but especially of power and control. In his crisis, Kushner came to conclude that although it was comforting to believe in God as an allpowerful rewarder of faith and protector of good people against tragedy in life, such a perspective and its associated defenses simply were not true. According to Kushner, the facts of life contain too much unfair, senseless suffering to be ignored. Nor do the facts support efforts to attribute all tragedy to the victim's sin, or to an appropriate timing for death, or to a privileged burden or need to be "tested" for spiritual self-discovery and growth. Injustice is not adequately vindicated in this world and may not be in the next; and in any event, the complacency that can result from a "compensation in the afterlife" belief is unfortunate. When tragedy does strike, a belief that God was responsible, that the tragedy was God's will, leaves the believer vulnerable to misdirected anger, depression, and alienation from God and others who could help.

In opting for "will not" over "cannot," for a God who could do otherwise but chooses to inflict severe suffering, Causation-Power-based beliefs defend God's power even at the expense of compromising some of God's goodness. Kushner's son's fatal illness, for example, was in the Causation-Power perspective consistent with God's will, indeed caused by God, for one reason or another. Kushner simply could not accept 
a God who would cause for any reason the sickness, disfigurement, and death of his innocent three-year-old son ("there was no reason God should have wanted that," p. 141). Similarly, Leslie Weatherhead (1944/1972) railed against such a view of God:

What sort of God is this, who of his own intention ... pours misery undeserved and unhappiness, disappointment and frustration, bereavement, calamity, and ill health on his beloved children, and then asks them to look up through their tears and say, "Thy will be done"? (pp. 14-15)

"Cosmic sadist" was C. S. Lewis's (1961, p. 35) term for such a God. In essence, Kushner's and Weatherhead's complaint is that CausationPower explanations of suffering compromise too much of God's love and goodness in the defense of God's omnipotence and fairness. At the least, we can agree with Kushner and other thinkers that the CausationPower perspective seems hard to reconcile with the facts of experience and does not solve the theodicic problem.

\section{Kushner's Reconstructed Faith: The Inspiration-Love Perspective}

At some point in Kushner's anguished reflection, a fundamental insight emerged:

All the responses to tragedy which we have considered have at least one thing in common. They all assume that God is the cause of our suffering ....

There may be another approach. Maybe God does not cause our suffering. Maybe it happens for some reason other than the will of God. (p. 29)

Kushner's emergent new approach, then, dissociated God from tragedy. His new approach augmented the sphere of human freedom and natural autonomy, thereby reducing the sphere of divine determinism. This approach also emphasized God's love and inspiring influence; hence, the reconstructed perspective could be termed "InspirationLove." Kushner argued that the Inspiration-Love perspective remedies the two serious limitations of the Causation-Power perspective. First, the Inspiration-Love perspective does not seek to minimize or distort the facts of tragedy; and second, it can, as a result, encourage more healthy emotional expression during tragic suffering. Anger should be directed not at God, who is on our side and would seek to comfort and console us, but instead at the tragedy itself:

Being angry at the situation, recognizing it as something rotten, unfair, and totally undeserved, shouting about it, denouncing it, crying over it, 
permits us to discharge the anger which is part of being hurt, without making it harder for us to be helped. (p. 109)

Such honest anger against unfair hurt, and related emotions such as compassion for the afflicted, are in a sense divinely inspired:

"Where do I get my sense of what is fair and what is unfair? Where do I get my sense of outrage and indignation, my instinctive response of sympathy when I read in the paper about a total stranger who has been hurt by life? Don't I get these things from God? Doesn't He plant in me a little bit of His own divine outrage at injustice and oppression, just as He did for the prophets of the Bible? Isn't my feeling of compassion for the afflicted just a reflection of the compassion $\mathrm{He}$ feels when $\mathrm{He}$ sees the suffering of His creatures?" Our responding to life's unfairness with sympathy and with righteous indignation, God's compassion and God's anger working through us, may be the surest proof of all of God's reality. (pp. 142-143)

The Inspiration-Love perspective better fits the "facts," according to Kushner, because it does not attempt to impute divine justice or purpose to every instance of suffering. God's goodness, love and sense of fairness are preserved because such suffering is not attributed to God: "it becomes much easier to take God seriously as the source of moral values if we don't hold Him responsible for all the unfair things that happen in the world" (p. 61).

But if tragedies are not attributable to God, then why do they happen? Kushner gave three reasons, two of them involving the necessity for allowing opportunities: first, for allowing humans the opportunity to make irresponsible choices as an inherent feature of their free will; and second, for allowing natural laws the "opportunity" to operate in an impartial and reliable manner. Kushner's third "reason" is rather ironic: tragic events may happen to a particular person by chance, for no reason at all.

Human abuse of free will. The clearest "reason other than the will of God" for unfair, senseless suffering is human free will. Whereas the Causation-Power perspective invoked free will to account for some suffering as God's punishment for sinful choices, the Inspiration-Love perspective invokes free will to account for the suffering of innocent persons as the result of an abuse of free will, the impact of an irresponsible choice by someone else:

God has set Himself the limit that He will not intervene to take away our freedom, including our freedom to hurt ourselves and others around us .... [O]ur being human leaves us free to hurt each other, and God can't stop us without taking away the freedom that makes us human. Human beings can cheat each other, rob each other, hurt each other, 
and God can only look down in pity and compassion at how little we have learned over the ages about how human beings should behave.... When people ask, "Where was God in Auschwitz? How could He have permitted the Nazis to kill so many innocent men, women, and children?", my response is that it was not God who caused it. It was caused by human beings choosing to be cruel to their fellow men ....

Christianity introduced to the world the idea of a God who suffers, ... who weeps when $\mathrm{He}$ sees what some of His children are doing to others of His children. (pp. 81 and 85)

Ever since God "had a new kind of creature emerge, a morally free animal who could choose to be good or bad ..., the world has seen a lot of nobility and a lot of cruelty" (p. 80).

Impartial laws of nature. Just as God could not renege on free will if humanity is to transcend the animal world, God could not infringe on the reliability and impartiality of natural laws if humanity is to survive and progress:

One of the things that makes the world livable is the fact that the laws of nature are precise and reliable, and always work the same way. There is gravity: heavy objects always fall toward the earth, so a builder can build a house without having his materials float away. There is chemistry: mixing certain elements in certain proportions always yields the same result, so a doctor can prescribe medication and know what will happen....

But the unchanging character of these laws, which makes medicine and astronomy possible, also causes problems. Gravity makes objects fall. Sometimes they fall on people and hurt them. Sometimes gravity makes people fall off mountains and out of windows. Sometimes gravity makes people slip on ice or sink under water. We could not live without gravity, but that means we have to live with the dangers it causes.

Laws of nature treat everyone alike. They do not make exceptions for good people or for useful people. If a man enters a house where someone has a contagious disease, he runs the risk of catching that disease. It makes no difference why he is in the house. He may be a doctor or a burglar; disease germs cannot tell the difference. If Lee Harvey Oswald [abuses his freedom and] fires a bullet at President John Kennedy, laws of nature take over from the moment that bullet is fired. Neither the course of the bullet nor the seriousness of the wound will be affected by questions of whether or not President Kennedy was a good person, of whether the world would be better off with him alive or dead. (pp. 57-58)

Kushner concluded: "A world in which good people suffer from the same natural dangers that others do causes problems. But a world in which good people were immune to those laws would cause even more problems" (p. 59). 
In Kushner's world of unchanging natural laws, the divine determinism of punishment is replaced by a natural determinism of lawful consequences:

The man who smokes two packs of cigarettes a day for twenty years and develops lung cancer, faces problems which deserve our sympathy, but he has no grounds for asking, "How could God do this to me?" ... Neither alas, will the doctor, the clergyman, or the politician who works long hours, seven-day week after seven-day week, in the noblest of causes, but fails to take care of his own health in the process. (p. 65)

Kushner's reconstructed perspective, then, makes a fundamental distinction between God and nature:

Nature is morally blind, without values. It churns along, following its own laws, not caring who or what gets in the way. But God is not morally blind ... . God stands for justice, for fairness, for compassion. (pp. 59-60)

Random chance. The senselessness of particular tragic events is addressed by Kushner's third factor, random chance. He asks: "Can you accept the idea that some things happen for no reason, that there is randomness in the universe? ... Why can't we let the universe have a few rough edges?" (pp. 46-47). Interestingly, according to quantum mechanics the "rough edges" of randomness may be inherent to the nature of the universe's subatomic reality (Davies, 1990). Despite the reliability of natural laws, including laws of probability, modern physics posits that the universe is partially indeterminate or stochastic at the level of individual events; for example, there is a genuine element of chance or unpredictability in whether a particular tossed coin will land heads or tails (Davies, 1990; Herbert, 1993). For Kushner, the role of chance means that we must accept that particular things may happen to particular people for no inherently meaningful or purposeful reason at all.

Random chance applies to both natural and human events. In the operations of the laws of nature, for example,

a random shift in weather patterns causes too much or too little rain over a farming area, and a year's harvest is destroyed .... An engine bolt breaks in Flight 205 instead of Flight 209, inflicting tragedy on one random group of families rather than another. There is no message in all of that. (p. 53)

There are also fluky events in the realm of human behavior:

To grab a gun and shoot at innocent people is irrational, unreasonable behavior, but I can understand it [as an abuse of free will]. What I 
cannot understand [as having a purpose or reason] is why Mrs. Smith should be walking on that street at that moment, while Mrs. Brown chooses to step into a shop on a whim and saves her life ... The lives of dozens of people will be affected by such trivial, unplanned decisions. (p. 47)

Kushner acknowledged that acceptance of the "whim" element or the absence of an inherent meaning or purpose in tragic events is a liability of the Inspiration-Love perspective, to which he offers an existentialist response:

"Does that mean that my suffering has no meaning?" That is the single most significant challenge that can be offered to the point of view I have been advocating in this book. We could bear nearly any pain or disappointment if we thought there was a reason behind it, a purpose to it. But even a lesser burden becomes too much for us if we feel it makes no sense. Patients in a veterans' hospital who have been seriously wounded in combat have an easier time adjusting to their injuries than do patients with exactly the same injury sustained while fooling around on a basketball court or a swimming pool, because they can tell themselves that their suffering at least was in a good cause. Parents who can convince themselves that there is some purpose somewhere served by their child's handicap can accept it better for the same reason....

Let me suggest that the bad things that happen to us in our lives do not have a meaning when they happen to us....

... We, by our responses, give suffering a positive or a negative meaning. Illnesses, accidents, human tragedies kill people. But they do not necessarily kill life or faith. (pp. 134-138)

Kushner cautioned that we may be left with randomness in perpetuity, suggesting a deistic position (Herbert, 1624/1937; Tindal, 1730/1978; Toland, 1696/1964):

[I]t may be that God finished His work of creating eons ago, and left the rest to us. Residual chaos, chance and mischance, things happening for no reason, will continue to be with us .... In that case, we will simply have to learn to live with it, sustained and comforted by the knowledge that the earthquake and the accident, like the murder and the robbery, are not the will of God, but represent that aspect of reality which stands independent of $\mathrm{His}$ will, and which angers and saddens God even as it angers and saddens us. (p. 55)

On the other hand, the sphere of indeterminacy may be diminished: "our world may not be a system left to itself. There may, in fact, be a creative impulse acting on it, ... operating over the course of millennia to bring order out of the chaos. It may yet come to pass that ... the impact of random evil will be diminished" (p. 55). This melioristic view 
is consistent with process theology (Griffin, 1976; Whitehead, 1929), a modern rendition (Davies, 1990) of which is quite compatible with Kushner's Inspiration-Love perspective on God:

God is responsible for ordering the world, not through direct action, but by providing the various potentialities which the physical universe is then free to actualize. In this way, God does not compromise the essential openness and indeterminism of the universe, but is nevertheless in a position to encourage a trend toward good. Traces of this subtle and indirect influence may be discerned in the progressive nature of biological evolution, for example, and the tendency for the universe to self-organize into a richer variety of ever more complex forms. Whitehead thus replaces the monarchical image of God as omnipotent creator and ruler [cf. Causation-Power perspective] to that of a participator in the creative process [cf. Inspiration-Love perspective]. (p. 183)

\section{The Inspiration-Love Perspective and Theodicy}

I believe in God. But I do not believe the same things about Him that I did years ago, when I was growing up or when I was a theological student. I recognize His limitations. He is limited in what He can do by laws of nature and by ... human nature and human moral freedom. (Kushner, 1981, p. 134)

If the Causation-Power perspective compromised some of God's love in defense of His power, perhaps the opposite can be said of the Inspiration-Love perspective. Is not a God who is "limited in what He can do," and who therefore cannot abolish evil, less than all-powerful? Perhaps no less troubling than a sadistic God is a weak one who suffers with us but cannot intervene.

Cannot intervene, in any sense? An important caveat is that God is not inherently limited in Kushner's argument. Rather, God has set Himself certain limits as a result of a kind of cost-benefit analysis in which the benefits of allowing free will, reliable natural laws, and open systems justify the costs. Furthermore, this benevolent non-intervention policy applies only to direct causal intervention. In the InspirationLove perspective, God does seek to "encourage a trend toward the good," in Paul Davies' phrase. As noted earlier, Kushner attributed our righteous indignation and compassion for the afflicted to divine inspiration. Generally,

God inspires people to help other people who have been hurt by life .... God makes some people want to become doctors and nurses, to spend days and nights of self-sacrificing concern with an intensity for which no money can compensate ... God moves people to want to be medical 
researchers, to focus their intelligence and energy on the causes and possible cures for some of life's tragedies ....

God, who neither causes nor prevents tragedies, helps by inspiring people to help.... God shows His opposition to cancer and birth defects, not by eliminating them or making them happen only to bad people (He can't do that), but by summoning forth friends and neighbors to ease the burden and to fill the emptiness ....

In the same way, I firmly believe that Aaron served God's purposes, not by being sick or strange-looking (there was no reason why God should have wanted that), but by facing up so bravely to his illness and to the problems caused by his appearance. I know that his friends and schoolmates were affected by his courage and by the way he managed to live a full life despite his limitations. And I know that people who knew our family were moved to handle the difficult times of their own lives with more hope and courage when they saw our example. I take these as instances of God moving people here on earth to help other people in need. (pp. 139-141)

In distinction to both a deistic positing of total non-intervention and a Causation-Power positing of direct causation, then, Kushner posited some intervention through inspiration or other indirect processes of influence. Similarly, David Lorimer (1990) suggested that the alternatives of either "the personal intervention of God or the total absence of such intervention" are rendered "less stark" by "arguments for intermediary forms of discarnate influence, as it were, on behalf of God" (p. 238). Once inspirational influences are posited, need they be restricted to the types described by Kushner? Could not one receive "inspiration" from some "discarnate influence," even to prevent tragedy? By expanding Inspiration-Love in the direction of Causation-Power, such a possibility can to some extent defend the Inspiration-Love perspective against the criticism that it merely trades a sadistic God for a weak one.

Kushner clearly regarded the Inspiration-Love perspective as a developmental advance, perhaps even a paradigmatic one (Kuhn, 1962), beyond the faith of his childhood, the Causation-Power perspective. But does the Inspiration-Love perspective succeed where the CausationPower perspective failed? Does it resolve the theodicic problem? Perhaps the Inspiration-Love perspective is more properly construed as an alternative position on the theodicic problem. In general, is there some basis for evaluating the relative adequacy of these two perspectives?

\section{Relevance of Near-Death and Related Research}

People who have been close to death and recovered tell of seeing a bright light and being greeted by someone they had loved, now deceased .... Needless to say, we have no way of knowing whether these 
visions are intimations of reality or products of our own wishful thinking. (Kushner, 1981, pp. 28-29)

I don't know what to make of NDE's, but people's testimonies are so heartfelt and so consistent that I am inclined to believe them. What I am least sure of is the verbal content of the experience. I am open to the possibility that they encountered the Divine (whatever that means) and tried to put that encounter into words .... It is possible then that they experienced love and reassurance ... (H. Kushner, personal communication, August 10, 1996)

In the remainder of this article, I will provide an empirically based evaluation of the respective validity of Kushner's original (CausationPower) and reconstructed (Inspiration-Love) perspectives on God and the theodicic problem. In a previous article, I evaluated similar positions on theodicy, respectively termed "Theistic-Sovereign" and "Theistic-Consoling" perspectives, on the basis of research concerning the near-death experience (NDE) (Gibbs, 1988). In the present article, I expand the empirical basis to include not only the NDE but also a related phenomenon, "after-death communication" (Guggenheim and Guggenheim, 1995/1997).

By far the greater amount of available ontologically relevant research pertains to the NDE, a set of extraordinary perceptions of both earthly and transcendental environments. The NDE is most likely to be experienced during clinical death or a comatose state. Although a comprehensive critique of near-death research is beyond the scope of this article, I suggest that NDE reports may entail genuine discoveries as to the ultimate nature of reality (Gibbs, 1985, 1997). This suggestion is consistent with the conclusions of investigators most familiar with the research data and findings (Ring, 1980, 1995; Ring and Lawrence, 1993; Ring and Valarino, 1998; Sabom, 1982, 1998). Kushner's observation, cited above, that the "testimonies are so heartfelt and so consistent" was supplemented by Kenneth Ring and Evelyn Elsaesser Valarino (1998):

Given both the consistent and insistent character of these avowals, it would be foolish and certainly cavalier to disregard this kind of testimony .... Furthermore ... think about the data ... the fantastic detail in panoramic visions while out of body, the sightings, while elevated, of dust, cobwebs, and other normally disregarded minutiae of our everyday environments; the miraculously acute perceptions of the nearly blind, and the "impossible" vision of the fully blind .... How does one ... explain the verified perception of those unlikely objects in improbable locations when no physical vision was possible at all, or, similarly, those overheard conversations that could not have been witnessed, or instances where NDErs have other information they could not conceivably have acquired by normal means? ... Children ... 
report essentially similar experiences to those of adult NDErs . . . Just as the NDE itself comprises a distinctive pattern of elements, so, too, were the changes that tended to develop in an NDEr's life afterward. In the realm of beliefs, values, behavior, and outlook on life generally, NDErs, however different they may have been before their experience, showed astonishing similarities. (pp. 55, 94-95, 99, and 123)

Certain researchers of both NDEs (Moody, 1975, 1977) and afterdeath communications (Guggenheim and Guggenheim, 1995/1997), have distilled a core prototype of generic elements or features from a large number of carefully studied cases. NDEs entail features that Michael Sabom (1982) termed autoscopic (especially, seeing one's physical body) and transcendental (especially, traveling toward a light, communicating with the light or deceased loved ones, and reviewing events of one's life). The relevance of the NDE to the theodicic problem is especially apparent in cases of NDErs who report having sought explanations for tragedy during their NDEs (see cases in the following section). Bill and Judy Guggenheim (1995/1997) defined the after-death communication as a spiritual experience, typically auditory and/or visual, "that occurs when someone is contacted directly and spontaneously by a deceased family member or friend" (p. 15). Careful study and description have been especially important with reference to the after-death communication, whose history has been rife with wishful thinking and fraud (Wilson, 1987).

In contrast to the NDE, in the after-death communication the experiencer is not near death. Nonetheless, findings suggest that the afterdeath communication, too, should be taken seriously, at least in some cases. First, some after-death communications were reported to have been simultaneously shared by independent witnesses. Second, some after-death communications conveyed information that the recipient could scarcely have known otherwise. Third, the prescience or timing of some after-death communications is remarkable. A nurse recounted this experience:

I was working in an extended care facility. Some of the patients were up and about, and Roland was one of those. We developed a special rapport. I realized he needed to feel needed, so I gave him little jobs to do, and he always seemed thrilled to do them.

One morning between 6:00 and 6:15, I was getting ready to go to work. I sat on the edge of my bed to put my shoes on. I turned my head and saw a faint vision of Roland standing at the foot of the bed, smiling! I recognized his face instantly. He looked happy and relaxed.

I thought I was going off the deep end! I smiled back at him, and then he was gone. I sort of laughed and said to my husband, "I'm really cracking up now. I'm not even at work yet, but I saw one of my patients standing here!" 
I went to work, and when I walked in, they told me that Roland had died of a heart attack during the night. I had the feeling he had come to let me know that he was all right. (Guggenheim and Guggenheim, $1995 / 1997$, p. 217)

In other cases, the death and visit are documented to have been contemporaneous. A physician, who had experienced an after-death communication from his grandmother, noticed the time and was able to gain corroboration that his grandmother had contemporaneously died:

I realized that ... she was saying, “Good-bye. Don't worry. Everything is fine."...

When I went home that day, my mother was waiting for me. She said, "Your grandmother has taken a turn for the worse." I told her, "Don't worry. I know what happened. She died at 10:10 this morning." Then my mother confirmed that my grandmother had died at exactly that time. (Guggenheim and Guggenheim, 1995/1997, p. 222)

Another subject even offered a correction as to the time of death based on the timing of an after-death communication:

The following morning my sister knocked on my front door. I knew why she had come and said, "You came to tell me that Grandpa died, didn't you?" She looked puzzled and said, "Mom called to tell us that he died of a heart attack at about 2:30 a.m." I said, "No, it was 2:17 a.m.," and I told her what had happened. (Guggenheim and Guggenheim, 1995/1997, p. 220)

Although anecdotal, such cases must be taken seriously not only because of the uncanny synchrony and other findings but also because the synchrony belies the usual interpretation of the after-death communication as a grief-induced hallucination. As the Guggenheims point out, after-death communications that take place prior to the experiencer's knowledge of the death can scarcely be attributed to grief-generated wishful fantasy. Like the NDE, the after-death communication is relevant to questions of God and tragedy.

\section{God, Tragedy, and the NDE: A Research-Based Evaluation of Kushner's Perspectives}

If the NDE and related phenomena entail some spiritual authenticity and are relevant to theological questions such as how to reconcile apparently unfair, senseless human suffering with an omnipotent, allgood and loving God, then these phenomena can provide an empirical 
basis for evaluating Kushner's Causation-Power and Inspiration-Love perspectives.

As noted earlier, the key issue for Kushner was whether tragedy and suffering reflect God's will. In the Causation-Power perspective, God is simply in charge, and tragic events do reflect God's will. Life may seem to be unfair and God may seem harsh; however, God does cause events, whether tragedies or miracles, and does see to it that we get what we deserve in life. Persons who are good are protected, and the perpetrators of evil ultimately will be punished. Apparently unfair or senseless suffering actually has some reason or purpose. For example, a person may need to suffer in order to be disciplined or to grow, or an apparently untimely death may have been that person's appropriate "time to go."

In the Inspiration-Love perspective, not every event reflects God's will; divine sovereignty is more complicated. If humans are to exercise conscious, free will and to live in the material world-a world that operates reliably but that is also an open system with room for chance and mischance-then bad things must be allowed to happen to good people. Rather than directly causing events, God works through people, inspiring them to care and to work against the unfair, senseless suffering that is all too evident in the world.

We will see that the relevant research provides some support for both perspectives. The most relevant NDEs for evaluating Kushner's perspectives are those of experiencers who had endured much unfair suffering - of good persons to whom bad things had happened-and who then sought an explanation during their NDEs. The overall impression imparted by two typical cases representing such NDEs is suggestive of the Causation-Power view. However, scrutiny of this impression in the context of a broader literature review suggests the prominence of a divine love that works through inspiration and human freedom, the Inspiration-Love perspective.

\section{Two Cases}

Like everyone else, NDErs have been touched by tragedy. As noted, particularly relevant to the present concern with Kushner's perspectives on tragedy are cases of NDErs who during their NDEs asked the light, identified as God, to explain hurts in life. Two such cases are those of women named Beverly Brodsky (Ring, 1991) and Lynn (Atwater, 1996).

Brodsky was "hurt" mainly by three tragic events or conditions. The first was the Holocaust. Raised in a Conservative Jewish family, she 
learned, at age 8, of the Holocaust: "I ... turned angrily against any early belief in God. How could God exist and permit such a thing to occur?" (Ring, 1991, p. 14). Brodsky's anger may have been prompted by the violation of what Kushner characterized as a childhood faith or what we have termed the Causation-Power perspective. Second, feeling "painfully shy and ... unworthy of being loved," she experienced serious depression during childhood and adolescence. The depression "reached a desperate phase" at the end of high school, rendering her "too upset to go to college ... [or face] the future" (p. 14). Third, shortly thereafter, her father died suddenly from a heart attack ("He had been my rock, my strength, in this world," p. 14).

Brodsky's near-death experience occurred several years after her father's death, when she was in her early 20 s. She had moved from home, and was in severe pain and depression from injuries from a serious motorcycle accident. She was lying in bed and, despite her atheism, praying "fervently" for death when:

Somehow an unexpected peace descended upon me. I found myself floating on the ceiling over the bed looking down at my unconscious body .... I then remember traveling a long distance upward toward the light .... There, before me, was the living presence of the Light. Within it I sensed an all-pervading intelligence, wisdom, compassion, love, and truth .... I immediately lashed out at Him ["Him" although there was neither form nor sex to this perfect Being] with all the questions I had ever wondered about; all the injustices I had seen in the physical world ... [especially] the question that had plagued me since childhood about the sufferings of my people [in the Holocaust]. (Ring, 1991, pp. 15-16)

Unfortunately, Brodsky stated, "in the process of return [to my broken body] the insights that came so clearly and fully in Heaven were not brought back with me" (p. 16). However, she did remember the insight that "there was a reason for everything that happened, no matter how awful it appeared in the physical realm .... All that happens is for a purpose" (p. 16).

The NDEr in the second case, Lynn, gained a similar impression during her NDE. Indeed, Lynn was given a particular "reason." Although Lynn did not report anger at God for the hurt in her life, she did consider the theodicic question to be "very important" and in her NDE did not wish to return to her body until after she asked the light for an explanation. Lynn's "hurt" included a physical handicap, a heart condition she had had since infancy. The heart problem made her sometimes "turn blue" and rendered her unable to "run and play like the other kids." Then, at the age of thirteen, her condition became critical. 
She was hospitalized and prepared for surgery, during which her NDE occurred:

[I was moving] towards the light .... It was a warm, living thing .... The light spoke, and it said, "Lynn, it is not time for you yet. Go back, child." ....

[The voice] was soft, yet there was strength in it. The voice made me feel secure, loved, wanted, protected .... Again the light said, "Lynn, go back. It is not time yet for you. You have work to do for me. Go back." .... The light ... then told me there were people who wanted to see me before I left. From out of the light came my maternal grandparents. I ran to them and embraced them. They were going to walk me part of the way back ....

My grandparents told me if I stayed longer I might not make it back. But I wanted to talk to Jesus. I grew up in parochial schools and I believed in Jesus. I had a very important question to ask him. A beam of light covered me, different from the first beam of light, yet similar in a way. I knew this light was Christ.

[T] hen I asked my question: "Dear Jesus, is it true that you gave me this heart condition so that I would have a cross to carry like you did?" (Sister Agnes, my sixth-grade teacher, told me that my heart condition was my cross to bear for Christ. That is why I asked this question.) I heard the voice of Christ vibrate through me as it said, "No, this heart condition is not a cross from me for you to bear. This heart condition of yours is a challenge to help you grow and stay compassionate. Now go back."

As I walked back to the tunnel with my grandparents ..., my grandmother told me my father was going to leave my mother and that I would be my mother's strength. (Atwater, 1996, pp. 9-10).

The "feel" of Brodsky's and Lynn's accounts is reminiscent of the Causation-Power perspective. Lynn described the light as "a warm, living thing" whose soft but strong voice made her feel secure and protected. Similarly, Brodsky felt she was in "the living presence" of an all-pervading, loving intelligence in whose realm even tragedies had a profound reason, meaning, or purpose. Lynn even returned with some recollection of those reasons: Her heart condition, although not a privileged burden, was a challenge to help her to "grow" and remain compassionate.

\section{Research Review}

The significance of Brodsky's and Lynn's accounts will be considered further through a review of other relevant research literature. Although Causation-Power themes continue to be evident, InspirationLove themes emerge prominently in the review. The review is structured 
around seven Causation-Power versus Inspiration-Love questions: (1) Do impressions that tragedy has some reason, purpose, or meaning imply that God causes tragedy? (2) Is one reason for tragedy an accident or mistake? Can death be truly untimely? (3) Are other reasons for tragedy (including suicide and murder) the neglect of divine warnings and, for that matter, the abuse of free will? (4) Does God punish those who abuse free will and who thereby cause tragedy? (5) Does God ever intervene directly in this world to reduce tragedy? (6) So is God primarily power or love?

1. Do impressions that tragedy has some reason, meaning, or purpose imply that God causes tragedy? It is probably unwise to treat the impressions of Brodsky, Lynn, or other NDE survivors as infallible (see Gibbs, in press; Zaleski, 1987); indeed, Kushner was skeptical of the verbal content of NDEs, as indicated in his quoted communication at the beginning of Section Two. Nonetheless, one aspect of Lynn's recollective impression does seem to relate to Kushner's question of whether God causes tragedy. Lynn did not represent the light as following the format of His previous statement ("This heart condition is not a cross from me for you to bear") by stating, "This heart condition is a challenge from me to help you ...," but instead represented the light as stating: "This heart condition of yours is a challenge ..." (emphasis added). Was the light implying that He did not cause the heart condition, did not want or intend for it to happen for the purpose of effecting the "challenge"? Consistent with the self's possible part-ownership of tragedy in some sense ("this heart condition of yours") is the suggestion that we may "choose from a world beyond this one" to enter a life that involves a handicap or traumas in order to "grow" through the "adversity," as one NDEr reported having learned (Durham, 1998). Kushner might point out, however, that such growth does not always take place.

The thesis that God does not cause tragedy is also consistent with the recollection of another experiencer who, during his life review,

got to see some good things I had done and some mistakes I had made, you know, and try to understand them. It was like: "O.K., here's why you had this accident, here's why this happened. Because so and so and so ...." It all had meaning. Definitely. (Ring, 1980, p. 73)

If God is in charge to the extent that randomness or chance does not exist, then why would this experiencer not have been told something more radical, such as "You did not really make a mistake," or "Here's why you had this apparent so-called accident"? The distinction is critical: "Saying that God can [inspire us to] find a purpose in an accident 
[Inspiration-Love perspective] is not the same as saying that God had a purpose for the accident" (Murphree, 1981, p. 46) and for that purpose caused the "accident," physical handicap, or other adverse event to happen (Causation-Power perspective).

Divine purpose as divine causation by a loving, good God would imply that genuine tragedies do not happen; in other words, that although bad things may appear to be happening to good people, this is not really the case. The data appear to be equivocal on this point. On the one hand, Brodsky gained the impression that even events as tragic as the Holocaust only "appear" to be "awful." On the other hand, another questioning experiencer reported being told by the light that "this time around you didn't get a benevolent and loving family" (note the hint of reincarnation), that "life was unfair," and that "there is evil in the world" (Cox-Chapman, 1995, p. 43). Furthermore, freak accidents and untimely death do take place, as discussed below.

Again, we do not know whether it follows from "reasons" for events that the light directly intends for tragic events, even challenging ones, to happen. At the least, we can state that whatever reason, meaning, or purpose there is in tragedy does not necessarily imply that God wanted the tragedy to happen and therefore caused it.

2. Is one reason for tragedy a random accident or mistake? Can death be truly untimely? That a tragic event may be a "fluky" accident or mistake finds some support in the research. In other words, there may indeed be a random or chance element to the universe. The accidental quality of at least some near-death occasions is implied by NDE messages such as Lynn's that the near-death occasion was "not the right time" for her to die, that she "might not make it back" if she stayed any longer, that her death at that time would be a mistake or premature; and therefore that she should go back (sometimes near-death experiencers are allowed to make the decision) because there is more for her to do on earth. The "more to do" typically involves spiritual growth and helping others. The particular near-death occasion, then, may be an accident or mistake, although this characterization may be simplistic. One experiencer who almost died during a bungled medical operation was told during her NDE:

What I understood at the time, how it was [telepathically] communicated to me was, "It is not your time yet. Go back. There has been a mistake." I look a lot differently at mistakes now, but at that point in my life it seemed simple: there's been a mistake and you have to go back. (Cox-Chapman, 1995, p. 47) 
Although NDErs are told that there will be an appropriate time for the end of their life, could another accident or mistake occur before then? Indeed, could not the next accident be so severe, for example, involving bodily obliteration or decapitation, as to preclude a return to the body? Perhaps the true tragedy is when one loses the opportunity to complete one's earthly purpose, as in Kushner's example of untimely and irretrievable deaths in an airplane crash. Indeed, one NDEr referred to "not accomplishing our work in this life" as "the only real fear" (Morse and Perry, 1990, p. 123).

Consistent with this possibility of untimely death and lost opportunity are some after-death communications, as well as the intuitions and conciliatory efforts of dying persons. A woman named Claire reported an after-death communication from her friend Hugh, noticing that:

his mood and expression were really sad, as though he had lost it all. Hugh said, "I'm sorry, Claire, I didn't make it." He added, "good-bye" as if forever. Then he just vanished. (Guggenheim and Guggenheim, 1995/1997, p. 219)

Subsequently, Claire learned that Hugh had drowned while trying to reach shore in a tragic boating accident. Guggenheim and Guggenheim speculated that those "who have died suddenly may initially feel bewildered, angry, sad, or cheated when their physical life is over" (p. 219). Dying persons often seem to have an intuitive sense of an "appropriate time" or occasion to die, and strive to live until the occasion or circumstances, often involving reconciliation or a "final gift" to a loved one, can be accomplished (Callanan and Kelley, 1992). Maggie Callanan and Patricia Kelley suggested the importance of helping the dying in this regard, and noted that appropriate deaths are not always achieved. Hence, the "appropriate time" defense of the Causation-Power perspective is not consistently supported. Accidents, mishaps, or mistakes do sometimes happen, and may constitute one reason for tragedy.

3. Are other reasons for tragedy (including suicide and murder) the neglect of divine warnings, and, for that matter, the abuse of free will? The research suggests that other reasons for tragedy may be the neglect of a prior divine warning and, for that matter, the abuse of free will. Imminent victims of tragedy may sometimes experience divine warnings that, if followed, could prevent a tragic crime, accident, or illness. Lynn recollected that the light's voice made her feel "secure" and "protected." Mitchell Liester (1998) reported in three cases of NDErs that two of the three continued to feel protected after their NDE, and all three reported 
post-NDE transcendent inner communications that included warnings of danger.

Such warnings relate to research on after-death communications, which exemplify what Lorimer called "intermediary forms of discarnate influence as it were on behalf of God" (1990, p. 238). Although many of the over 2000 after-death communications studied by Guggenheim and Guggenheim involved simple reassurances to grieving survivors that the visitors are all right and the survivors should get on with their lives, some survivors "received warnings that protected them from motor vehicle or other accidents, harm from criminals, house fires, industrial injuries, undiagnosed health problems, and emergencies involving infants and young children" (1995/1997, p. 257; see also Moody, 1977, pp. 23-28).

Such communications suggest that the "inspirational influence" of Kushner's Inspiration-Love perspective could be expanded beyond promptings to cope with tragedy and care for others, to include promptings to prevent tragedy. A focus on whether such promptings are heeded brings us perilously close to blaming the victim; nonetheless, the possibility of such a phenomenon is important to consider. Recall Kushner's hypothetical "random evil" example cited earlier: Could Mrs. Brown, who stepped "into a shop on a whim" and thereby avoided a fatal bullet, have felt an intuition instead of a whim? Could Mrs. Smith, who kept walking and was killed by the gunman's bullet, have neglected a warning intuition?

Successful warning communications would certainly seem consistent with the Causation-Power thesis that God protects good people from harm. A closer inspection, however, suggests an Inspiration-Love caveat: the protection is only potential; all that is provided is a warning communication that respects human free will ("since you always retain your free will, you can choose to accept or reject [this] guidance"; Guggenheim and Guggenheim, 1995/1997, p. 243) as well as the autonomy and reliability of nature's laws (the warning is necessary precisely because natural laws remain in full force). Although NDE survivors and Causation-Power believers may feel protected, actual protection may require both attention and response to warning intuitions and inspirations. Needless to say, the researchers advised the responsible exercise of free will:

How many ... tragedies might be prevented if more people were open and receptive to having $\mathrm{ADC}$ [after-death communication] experiences and trusted them? In the course of our research, we spoke with several people who unfortunately failed to act upon the guidance they were 
given and later came to bitterly regret it. We urge everyone, especially parents of young children, to immediately respond to their intuitive feelings and [after-death communications] whenever they have them. (Guggenheim and Guggenheim, 1995/1997, p. 260)

The researchers prescribed meditation as one way to promote greater discernment of and receptivity to intuitive inspirations and after-death communications. Liester (1998) speculated that NDEs may tend to render individual human consciousness more sensitive to intuitions of divine guidance. Identifying appropriate criteria for discernment is, of course, crucial. Perhaps one criterion is brevity or simplicity. Since the inspirations of NDEs and after-death communications-at least those that are remembered-tend to be fairly brief, elaborate and extensive teachings-such as those claimed in the 1997 "Heaven's Gate" tragedy - can be identified as suspect. In a study of 160 adults in the Southeastern United States, Sabom (1998) distinguished between NDE survivors' spiritual faith and their religious orientation. He concluded that the NDE deepened their spiritual faith and simply communicated love (an example of "general revelation"), but did not specifically inform or change their religious orientation; in most cases, religious orientation instead remained consistent with prior religious background. The message of love is simple but sublime, suggestive of what William James (1903/1958) called "immediate luminousness" (p. 32). Love also passes James' other criteria for spiritual authenticity: "philosophical reasonableness" (its "relations to the rest of what we hold as true") and "moral helpfulness" (its benefits for "conduct and character"; pp. 32 and 34). Ring and Valarino (1998) suggested that love and related themes of the NDE are "akin to Type $O$ blood in transfusions: They are the 'universal donor' to spirituality and religion in that they fit easily and well into a great variety of well-established spiritual traditions and world religions" (p. 302).

After-death communications or NDEs have also dissuaded some individuals from choosing to commit suicide or murder. Selfishly motivated murder and suicide are tragic actions that would certainly seem to be inconsistent with God's will and hence to reflect irresponsible choices. One man during his NDE

got the feeling that two things it was completely forbidden for me to do would be to kill myself or to kill another person.... If I were to commit suicide, I would be throwing God's gift back in his face .... Killing somebody else would be interfering with God's purpose for that individual. (Moody, 1975, p. 144) 
Messages against suicide are prominent in NDEs (Greyson, 19921993) as well as in after-death communication reports. Guggenheim and Guggenheim described "anti-suicide interventions" as "a specialized form of $\mathrm{ADCs}$ for protection that occur at the critical moment someone truly needs encouragement" (1995/1997, p. 271). For example, a woman who was depressed and seriously contemplating suicide saw a light and heard the voice of her boyfriend Terry's deceased grandmother:

\begin{abstract}
She said that my family and Terry's family would not understand why I had terminated my life. And that life was too precious to give up. She reassured me that I was loved and would truly be missed. She told me that suicide was not the answer. She had made that mistake herself, but I should not make that mistake, too.

It was like she encompassed me and surrounded me. I felt a warmth inside of me that I had never felt before. She gave me an inner strength, and I felt that I could do anything that I wanted to do at that point. Then the light was gone. (p. 277)
\end{abstract}

Interestingly, warning after-death communications may also be experienced by chronic violent offenders. Samuel Yochelson and Stanton Samenow (1976) found that approximately 50 percent of the violent adult male felons they studied reported that they

hear a voice speaking to them at critical times .... The voice emerges for only a moment when the criminal is about to violate but is still hesitant. With increasing violation, many criminals hear the voice more frequently and intensely .... The voice urges him to refrain from committing the crime .... They consider the voice as ordinary as having eyes and ears and are astonished to discover that most people do not hear one.

The criminal does not have control over whether the voice makes its presence known. But he can decide whether to heed its message .... While considering whether to molest a child sexually, $C$ heard the voice of his deceased father saying, "Don't." When he wanted to proceed with the crime, he could break the communication with his father and simply ignore the voice. (pp. 424-426)

Although Yochelson and Samenow described these incidents in psychological terms as "nonpsychotic auditory hallucinations" from repressed consciences, we can suspect that at least some of the "hallucinations" may be after-death communications. Note that like the suicide contemplators, the criminals heard the voice "at critical times" prior to the act.

We can sympathize with the victims of a human evil more readily than we can with its perpetrators; put differently, the victimizer deserves 
more blame than the victim. Those who do not merely neglect or dismiss an intuition but instead willfully defy a divine warning and proceed to harm another person or themselves illustrate another reason for human tragedy: the abuse of human free will.

Free will would appear to qualify the thesis of divine determinism emphasized in the Causation-Power perspective. In positive terms reminiscent of the Inspiration-Love perspective, one experiencer explicitly affirmed "free will [as] the most powerful characteristic that God gave [to humans]. [Choosing] love is a way of expressing the divinity of the human condition" (Farr, 1993, p. 134). This experiencer had the impression that although his NDE was predestined, the particular neardeath occasion for the NDE was not: "If the truck did not fall on me, I would have been hit by a car crossing the street [or something else would have happened]" (Farr, 1993, p. 53); hence, the specifics were "partially" (p. 145) a matter of his free-will decisions or choices. Similarly, the "work" in the typical NDE message "There is more work for you to do" may be unspecified because the particular path has not been fully predetermined. Despite forecasts and flashforwards that may subsequently materialize, as in the case of Lynn, whose father did in fact subsequently abandon the family, destiny may be partially contingent on human choices. Choices ranging from neglect to willful defiance may constitute additional reasons for tragedy.

4. Does God punish those who abuse free will and who thereby cause tragedy? There is some encouragement for the Causation-Power notion that persons at least ultimately "get what they deserve," albeit again with Inspiration-Love caveats: the just desserts are administered by the self, not by God, and their purpose may extend beyond retribution. The research suggests that God remains loving and at most provides the conditions for self-judgment and spiritual consequences.

For example, during the life review element of the NDE, the light serves as a source of acceptance and encouragement to choose love, while the locus for the judgment or evaluation of the events reviewed is the self. The self may feel "ashamed," "very repentant" (Moody, 1975, p. 69), "awful, [cringing] with remorse" (Mesa, 1998), or even "devastated" (Farr, 1993, p. 34), especially in the so-called "empathic life review" in which one directly experiences the emotional effects of one's actions on others (Ellwood, 1996). Gracia Fay Ellwood called the empathic life review experience "an exact sort of recompense" or "perfect justice," although she also pointed out that its purpose appears to be broader than that of retribution. Throughout this self-judgment, the 
light's love, understanding, and acceptance continues. Mally CoxChapman (1995) inferred from her cases that the purpose of such life reviews is "not to arrive at a fair punishment but to attain the clarity needed to move closer to God's love" (p. 68), or to grasp more clearly one's "true purpose" (p. 73). Nonetheless, the prospect of the empathic life review enriches the notion that when we cheat or harm others, we are ultimately cheating or harming ourselves.

The afterlife consequences of selfish suicide, of "throwing God's gift back in His face," would appear to be a kind of limbo, separate from both earthly life and God (except perhaps if one prays for forgiveness; Rogers, 1998). NDE survivors from suicide attempts report that their problems were still present: "In their disembodied state they were unable to do anything about their problems, and they also had to view the unfortunate consequences which resulted from their acts" (Moody, 1975, p. 143). The boyfriend's deceased grandmother quoted above told the suicide attempter that her own decision to commit suicide was a "mistake." Guggenheim and Guggenheim suggest that deceased individuals who had committed suicide perhaps are "making amends" (1995/1997, p. 260) and are especially appropriate candidates to "come back to motivate others to make wiser choices" (p. 276).

Would-be suicide attempters are sometimes accordingly warned not only in after-death communications, but during an NDE as well. One such warning was experienced by a man who was accidentally knocked unconscious as he was about to commit suicide. While unconscious, he experienced himself

going ... to an emptiness. And then, all of a sudden, I heard this voice ... like someone talking to me as a real close friend .... The first thing he said was, "Do you really want to die?" and I said, "Yes. Nothing has been going right all my life and at this point I really don't care if I live or die." And he says, "What about your mother? She cares about you. What about your girl friend?" And then it got kind of hazy and he said something about a daughter but-I don't have a daughter! So I think it's sort of like, some time in the future I'm going to have a daughter and she's going to be something important, because if God wants me to live, there must be some purpose to my life .... And he goes, "You're breaking my laws to commit suicide. You'll not be with me in heaven-if you die." (Ring, 1980, p. 76)

If suicide has the consequence of excluding the perpetrator from heaven, then perhaps perpetrators of the injustices associated with other tragedies such as murder are similarly excluded. In some cases, even self-judgment can be tantamount to an experience of hell: 
Those who engineered the Nazi atrocities seem to have been people whose lack of love was so complete that they willed the deaths of millions of innocent persons. This resulted in countless individual tragedies of separation of parent from child, of husband from wife, of friend from friend. It resulted in innumerable long, lingering deaths and fast brutal ones. It resulted in awful degradations, in years of hunger, tears, and torment for their victims. If what happened to my subjects happened to these men, they would see all these things and many others come alive, vividly portrayed before them. In my wildest fantasies, I am totally unable to imagine a hell more horrible, more ultimately unbearable than this. (Moody, 1977, p. 171)

In general, hell may be the afterlife separation from the light, engendered by human ego, pride, or vanity, and other self-centered attitudes, choices, or actions (Berman, 1996). In C. S. Lewis's memorable assertion, perhaps "the doors of hell are locked from the inside" (1944/1966, p. 127).

5. Does God ever intervene directly against tragedy? Consistent with the Inspiration-Love emphasis on the autonomy of nature, post-NDE physical recoveries are typically "normal," that is, painful and slow. Consistent with the Causation-Power idea of direct causal divine intervention, however, are occasional reports of a sudden, miraculous recovery from a near-death condition or of miraculous healings effected by NDErs (Liester, 1998; Moody, 1975, pp. 105-107; Ring, 1998; Ring and Valarino, 1998, pp. 222-227; Sabom, 1998). Kushner may give some ground here, since he seems less than completely confident that God never goes beyond inspiration to causation: "Sometimes miracles do happen. Malignancies mysteriously disappear; incurable patients recover, and baffled doctors credit it to an act of God. All we can do in a case like that is echo the doctor's bewildered gratituden (p. 116). Kushner would appear to be suggesting that even the Inspiration-Love perspective may not completely fit the facts of his pastoral experience.

One interesting suggestion from Ring (1991) is that the NDE itself may sometimes be a kind of intervention. He speculated, as did CoxChapman subsequently (1995, p. 43), that

the NDE may sometimes be almost like a compensatory gift vouchsafed to those who have had to endure the terrible wounds of [abusive or stressful] childhoods .... [NDE revelations and inspirations that impart the healing clarity of deep compassion and self-understanding] help the individual gain a compensatory edge in coping with and understanding life's difficulties. (Ring, 1991, p. 12)

Similarly, Barbara Rommer (1998) found that violence victims who have NDEs or out-of-body experiences during the violence are more 
likely subsequently to forgive (but not condone) the assault and to recover emotionally; Rommer attributed these effects to the NDE's responsiveness to each experiencer's particular needs and its stimulating "astounding spiritual growth." Post-NDE benefits were evident in Brodsky's and Lynn's cases. Following her experience with the light's love, Lynn became "openly confident and trusting" (Atwater, 1996, p. 10). Similarly, Brodsky "drew" from the light's acceptance and love a sense of "life and joy beyond imagining." Following her return, she found that this new love and joy had eradicated her previous "painful" shyness and feeling of being "unworthy of being loved," and gave her the courage to live life to the fullest. She initiated new relationships, reconciled with her mother, achieved in college, married, and launched a career. However, other research has shown that post-NDE life is not always easy (Atwater, 1988; 1996; Sutherland, 1992/1995, pp. 205-237).

6. So is God primarily power or love? NDErs' descriptions of the light, taken at face value as informative of the nature of God, suggest that God is both sovereignty or power, as emphasized in Causation-Power, and love or compassion, as emphasized in Inspiration-Love. Both are "primary." For example, Brodsky sensed "an all-pervading intelligence, wisdom, compassion, love, and truth." Medieval NDE accounts, too, refer to "a light that is at once all-knowing and all-loving" (Zaleski, 1987, p. 125). Lynn described the light as "a warm, living thing .... [The voice] was soft, yet there was strength in it. The voice made me feel secure, loved, wanted, protected." Another respondent reflected: "There's such love and great warmth and [pause] and security and strength in that ... that ... All-Being, that All-Presence that is there. Whatever it is that's out there, that's the presence. There's great comfort" (Ring, 1980, p. 72 ). One respondent explicitly referred to "a very powerful, completely loving being" (p. 70).

It should be noted, however, that experiencers are more impressed with divine love than divine power. One experiencer reported:

Far more even than power, what emanated from this Presence was unconditional love. An astonishing love. A love beyond my wildest imagining. This love knew every unlovable thing about me ... every mean, selfish thought and action since the time I was born ... and accepted and loved me just the same. (Ritchie and Sherrill, 1978, p. 49; see also Cox-Chapman, 1995, p. 24)

Furthermore, the teaching in the life review typically emphasizes love:

Through all this [life review], he kept stressing the importance of love. The places where he showed it best involved my sister. I have always 
been close to her. He showed me some instances where I had been selfish to my sister, then just as many times where I had really shown love to her and had shared with her. He pointed out to me that I should try to do things for other people, to try my best. There wasn't any accusation in any of this, though. When I came across times when I had been selfish, his attitude was that I had been learning from them, too. (Moody, 1975, p. 67)

Similarly, another experiencer reported:

I knew beyond any doubts that whatever he would see in me, he would understand and accept. His love encouraged me to go through my life up to that point. I saw, relived, remembered things that had happened in my life [especially with my younger brother]: not only what actually took place but also the emotions involved ... and because of the love and understanding radiating from the being of light, I found the courage to see for myself, with open eyes and without defenses [such as "who started" the incident], what in my actions and feelings made my brother happy, and what caused him pain. And for most of the episodes we went through the being offered me an alternative way to act.... [He offered] an open invitation .... I felt totally free and respected. Needless to say, his suggestions were all for a more loving and understanding attitude. (Ring, 1991, p. 37; see also Cox-Chapman, 1995, pp. 66-69)

Especially noteworthy for the Inspiration-Love emphasis on inspiration and free will is how being accepted, understood, and loved, enabled the subject to gain the courage to see life non-defensively and to consider freely the light's "open invitation" and "suggestions" for living a more loving life. Although NDErs experience both power and love as emanating from the light, love is more salient.

\section{Conclusion}

Was Kushner's Inspiration-Love perspective, then, a theological advance beyond his earlier Causation-Power perspective? Despite the initial impression imparted by case studies, the NDE and related research literature do suggest a "tilt" toward love, inspiration, and encouragement versus power, causation, and control. Controlling power is scarcely suggested when NDE survivors are told in the experience that life is unfair or that the precipitating event, such as a botched medical operation, was a mistake, or receive an answer implying that God did not cause one's unfair suffering, such as a debilitating heart condition in childhood. After-death communications may warn, sometimes 
unsuccessfully, against imminent tragedy, and untimely or inappropriate deaths do seem to occur.

As Kushner emphasized, love over control means that persons are granted the free will to choose to be self-centered or unloving, even to ignore the warning voice of a deceased loved one in order to commit murder, sexual molestation, or other violent crime. More than controlling power, inspiring love is suggested when NDE survivors report having experienced an overwhelming, unconditional acceptance; when caring and understanding attitudes are encouraged through the life review; when selfish suicide and murder are understood to transgress against God's love; and when the "more work" for the self to do after returning involves helping others. The theme of inspiration and love is pervasive, then, across aspects of the NDE, its after-effects, and related phenomena. This theme is also evident but less pervasive in NDE accounts from medieval times, perhaps because those accounts were often re-worked to support the then-prevalent punishment-oriented religious ideology (Zaleski, 1987).

Before we follow Kushner and reject the Causation-Power perspective entirely, however, we must note that the power theme is far from absent in the NDE and related literature. NDE survivors report having experienced feelings of comfort and security not only from the light's love, but also from its "strength." Although they are not told that God causes tragedy, they do gain a sense that there is a reason or meaning or purpose for all that happens. Indeed, some NDEs themselves may have been intended to happen in one way or another, as an intervention against a self-destructive life or as a compensatory gift for a hitherto tragic one. Sometimes, medically miraculous physical healings may take place. And perhaps, as the Causation-Power perspective claims, we do at least ultimately "get what we deserve": we noted the "perfect justice" (and benefit) of the empathic life review in which one experiences the sufferings of one's victims (or the joys of one's beneficiaries), and the possibility that those who committed selfish suicide must "make amends."

Hence, the Inspiration-Love approach to faith represents an advance, but not in the strong sense, such as a resolution of the theodicic problem or the construction of a new paradigm that renders entirely obsolete its predecessor. Rather, the advance is more like a needed shift in emphasis, a reversal of figure and ground, a tilt toward love and inspiration. The Inspiration-Love perspective does indeed remedy the serious limitations of the Causation-Power perspective, limitations that distort our understanding of God and tragedy in harmful ways. For example, those 
angry at God for having caused their tragedy may dissolve their anger as they understand that God did not inflict their tragedy, did not will it as a privileged burden, and is "on their side" in life.

Could not, however, Inspiration-Love also potentially engender certain distortions that in turn need a corrective? For example, in the focus on divine love, might we lose sight of divine strength? In the focus on human and natural autonomy, might we miss the potential for divine guidance? It is almost as if a kind of Heisenberg uncertainty principle operates in metaphysics, dictating the impossibility of capturing both love and power attributes of God; as if the best we can do is to oscillate between one attribute and its complement, attempting through the oscillation to approach a full understanding of God. Power and love, causation and inspiration, justice and acceptance: each attribute, then, corrects its complement, and, though we may tilt toward Inspiration-Love, both are indispensable for understanding God. Without love, CausationPower reduces to the sadistic infliction of suffering; and without power, Inspiration-Love reduces to a passive hand-wringing useless against evil and chaos.

The theoretical physicist Neils Bohr deeply believed in complementarity as a widely applicable "conceptual framework" (Folse, 1985, p. 10), the most famous example being light's behavior as both a particle and a wave; each attribute by itself "seems irreconcilably different" from the other (Herbert, 1985). Neither is reducible to the other, and both are needed for a complete understanding of light: "the nature of light [and the light?] is such that it is able to combine these contradictory attributes in a harmonious way" (Herbert, 1985, p. 38; parenthetical comment added). Bohr argued that our greatest understanding of reality is achieved through "the exhaustive overlay of different descriptions that incorporate apparently contradictory notions" (Holton, 1970, p. 1018).

Gerald Holton noted that Bohr's (1963) complementarity framework has never become a prominent philosophy, perhaps because it goes against the natural resistance to accepting "basic dualities without straining for their mutual dissolution or reduction" (1970, p. 1049). James (1903/1958) noted incompatible doctrines pertaining to the varieties of religious experience, lamenting that "they neutralize one another and leave no fixed result" (p. 387), but sought to identify that which was "common and generic" (p. 388) among the doctrines. Working with incompatible ideas is even more difficult when the ideas afford no common ground. Albert Einstein attempted for decades and failed to find "the logical connection" that would permit a resolution of the wave-particle paradox (Einstein, 1924, cited in Holton, 1970, p. 1017). 
In Hegelian terms, the natural tendency is to seek to resolve the tension of thesis and antithesis through the achievement of some synthesis or integration.

Perhaps a resolution of the theodicic paradox can be achieved. Towards that end, Kushner's perspectives are heuristic. Furthermore, the "tilt" in the research can be interpreted as supporting Kushner's essential message, namely, that love and inspiration are more central than power and direct causation to the relevance of God for humanity. During the life review, the self judges and learns in the context of the continued love and guidance of the light. The self-centered self can even abuse free will to create its own hell, essentially a willful separation from God's love. The self who returns from the NDE is typically rather selfless, devoted to helping and caring for others in one way or another.

An integrative understanding of God and tragedy perhaps lies beyond this realm and need not be complicated. The grieving Lewis (1961) wrote in his diary:

Heaven will solve our problems, but not, I think, by showing us subtle reconciliations between all our apparently contradictory notions. The notions will all be knocked from under our feet. We shall see that there never was any problem.

And, more than once, [I sense] that impression which I can't describe except by saying that it's like the sound of a chuckle in the darkness. The sense that some shattering and disarming simplicity is the real answer. (p. 83)

The questioning experiencer Brodsky gained a similar impression:

And within myself, as I was given the answer [to the problem of tragedy and suffering], my own awakening mind now responded ... "Of course," I would think, "I already know that. How could I ever have forgotten!" (Ring, 1991, p. 16)

\section{References}

Atwater, P. M. H. (1988). Coming back to life: The after-effects of the near-death experience. New York, NY: Dodd, Mead.

Atwater, P. M. H. (1996). Children and the near-death phenomenon: Another viewpoint [Guest editorial]. Journal of Near-Death Studies, 15, 5-16.

Berman, P. L. (1996). The journey home: What near-death experiences and mysticism teach us about the gift of life. New York, NY: Pocket Books.

Bohr, N. (1963). Essays 1958-1962 on atomic physics and human knowledge. New York, NY: Wiley.

Callanan, M., and Kelley, P. (1992). Final gifts: Understanding the special awareness, needs, and communications of the dying. New York, NY: Poseidon.

Chuan-Eoan, H. (1996, July 29). Terror on flight 800. Time, 26-39. 
Cox-Chapman, M. (1995). The case for heaven: Near-death experiences as evidence of the afterlife. New York, NY: Putnam.

Davies, P. (1990). The Mind of God: The scientific basis for a rational world. New York, NY: Simon and Schuster.

Durham, E. (1998, October). Panel A of experiencers. Presentation at the International Association for Near-Death Studies North American Conference, Salt Lake City, UT.

Ellwood, G. F. (1996). Distressing near-death experiences as photographic negatives. Journal of Near-Death Studies, 15, 83-114.

Farr, S. S. (1993). What Tom Sawyer learned from dying. Norfolk, VA: Hampton Roads.

Folse, H. J. (1985). The philosophy of Niels Bohr: The framework of complementarity. Amsterdam, The Netherlands: North-Holland/Elsevier.

Gibbs, J. C. (1985). Moody's versus Siegel's interpretation of the near-death experience: An evaluation based on recent research. Anabiosis: The Journal of Near-Death Studies, $5,67-81$.

Gibbs, J. C. (1988). Three perspectives on tragedy and suffering: The relevance of neardeath experiance research. Journal of Psychology and Theology, 16, 21-33.

Gibbs, J. C. (1997). Surprise-and discovery?-in the near-death experience. Journal of Near-Death Studies, 15, 259-278.

Gibbs, J. C. (in press). Review of Light and death: One doctor's fascinating account of near-death experiences. Journal of Near-Death Studies.

Greyson, B. (1992-93). Near-death experiences and antisuicidal attitudes. Omega, 26, 81-89.

Griffin, D. (1976). God, power, and evil: A process theodicy. Philadelphia, PA: Westminster.

Guggenheim, B., and Guggenheim, J. (1997). Hello from heaven: A new field of research confirms that life and love are eternal. New York, NY: Bantam. (Original work published in 1995).

Herbert, E. (1937). De veritate. Bristol, England: University of Bristol Publishers. (Original work published in 1624).

Herbert, N. (1985). Quantum reality: Beyond the new physics. New York, NY: Doubleday.

Herbert, N. (1993). Elemental mind: Human consciousness and the new physics. New York, NY: Penguin.

Holton, G. (1970). The roots of complementarity. Daedalus, 99, 1015-1055

James, W. (1958). The varieties of religious experiences: A study in human nature. New York, NY: Mentor Books. (Original work published 1903).

Kuhn, T. S. (1962). The structure of scientific revolutions. Chicago, IL: University of Chicago Press.

Kushner, H. S. (1981). When bad things happen to good people. New York, NY: Schocken Books.

Lerner, M. (1980). The belief in a just world: A fundamental delusion. New York, NY: Plenum.

Lewis, C. S. (1961). A grief observed. New York, NY: Seabury.

Lewis, C. S. (1966). The problem of pain. New York: Macmillan. (Original work published 1944).

Liester, M. B. (1998). Inner communications following the near-death experience. Journal of Near-Death Studies, 16, 233-248.

Lorimer, D. (1990). Whole in one: The near-death experience and the ethic of interconnectedness. London, England: Penguin.

Mesa, J. (1998, October). Panel A of experiencers. Presentation at the International Association for Near-Death Studies North American Conference, Salt Lake City, UT.

Moody, R. A. (1975). Life after life. Covington, GA: Mockingbird Books.

Moody, R. A. (1977). Reflections on life after life. St. Simon's Island, GA: Mockingbird Books.

Morse, M., and Perry, P. (1990). Closer to the light: Learning from children's near-death experiences. New York, NY: Villard. 
Murphree, J. T. (1981). A loving God and a suffering world: A new look at an old problem. Downers Grove, IL: InterVarsity.

Ring, K. (1980). Life at death: A scientific investigation of the near-death experience. New York, NY: Coward, McCann and Geoghegan.

Ring, K. (1991). Amazing grace: The near-death experience as a compensatory gift. Journal of Near-Death Studies, 10, 11-40.

Ring, K. (1995). [Review of Dying to live: Science and near-death experience.] Journal of Near-Death Studies, 14, 117-132.

Ring, K. (1998, October). They came by light: Healing gifts and the NDE. Presentation at the International Association for Near-Death Studies North American Conference, Salt Lake City, UT.

Ring, K., and Lawrence, M. (1993). Further evidence for veridical perception during neardeath experiences. Journal of Near-Death Studies, 11, 223-229.

Ring, K., and Valarino, E. E. (1998). Lessons from the light: What we can learn from the near-death experience. New York, NY: Plenum.

Ritchie, G., and Sherrill, E. (1978). Return from tomorrow. Waco, TX: Chosen Books.

Rogers, S. E. H. (1998, October). Suicide and the near-death experience. Presentation at the International Association for Near-Death Studies North American Conference, Salt Lake City, UT.

Rommer, B. R. (1998, October). NDEs following violence: Resultant positive spiritual growth. Presentation at the International Association for Near-Death Studies North American Conference, Salt Lake City, UT.

Sabom, M. B. (1982). Recollections of death: A medical investigation. New York: Harper and Row.

Sabom, M. B. (1998). Light and death: One doctor's fascinating account of near-death experiences. Grand Rapids, MI: Zondervan.

Shweder, R. A., Much, N. C., Mahapatra, M., and Park, L. (1997). The "Big Three" of morality (autonomy, community, divinity) and the "Big Three" explanations of suffering. In A. M. Brandt and P. Rozin (Eds.), Morality and health. New York, NY: Routledge.

Sutherland, C. (1995). Reborn in the light: Life after near-death experiences. New York, NY: Bantam. (Original work published as Transformed by the light in 1992).

Tindal, M. (1978). Christianity as old as the creation: Or the Gospel a republication of the religion of nature. New York, NY: Garland. (Original work published in 1730).

Toland, J. (1964). Christianity not mysterious. Stuttgart, Germany: F. Frommann. (Original work published in 1696).

Weatherhead, L. D. (1971). The will of God. Nashville, TN: Abingdon. (Original work published in 1944).

Whitehead, A. N. (1929). Process and reality. New York: Macmillan.

Wilson, I. (1987). The after death experience: The physics of the non-physical. New York, NY: Morrow.

Yochelson, S., and Samenow, S. E. (1976). The criminal personality. Vol. 1: A profile for change. New York: Aronson.

Zaleski, C. (1987). Otherworld journeys: Accounts of near-death experience in medieval and modern times. New York: Oxford University Press. 